\title{
MATHEMATICAL MODELING OF GRAIN DRYING 1
}

\author{
R. ČIEGIS ${ }^{1}$, T. LEONAVIČIENE ${ }^{1}$, V. SKAKAUSKAS ${ }^{2}$, O. SUBOČ $\check{S}^{1}$ \\ ${ }^{1}$ Vilnius Gediminas Technical University \\ Saulètekio al. 11, LT-2040, Vilnius, Lithuania \\ E-mail: $\{r c, t l, o s\} @ f m . v t u . I t$ \\ ${ }^{2}$ Vilnius University \\ Naugarduko Str. 24, LT-2060, Vilnius, Lithuania \\ E-mail: Vladas.Skakauskas@maf .vu.lt
}

Received March 28, 2003; revised May 10, 2003

\begin{abstract}
In this paper we consider the mathematical model which describes the grain drying process. The air and grain moisture and temperature are described by a system of PDE. A finite difference scheme is proposed for finding a numerical solution. The convergence of the discrete solution is proved for a simplified model, when the temperature is assumed to be given a priori. Results of numerical experiments are presented.
\end{abstract}

\section{INTRODUCTION}

Various types of grains are important resources which have a wide variety of uses. At some stage of production all grains undergo a drying process. As in many other industries where drying is used, e.g. drying of wood or the other porous materials $[3 ; 6 ; 8 ; 13]$, reducing drying times allow a reduction in the energy consumption and a better quality of the final product. Mathematical modeling can play a significant part in optimization of existing grain drying technologies and in introduction of new drying processes.

The basic physical and thermodynamic properties of grain and air are examined and the theory of the drying process is developed in $[1 ; 7]$. The design of the optimum operating conditions for grain dryers is presented in $[11 ; 12]$.

In this paper a grain drying problem is carried out using a very simple

\footnotetext{
${ }^{1}$ This work was supported by Eureka grant OPTPAPER EU-2623, E-2002.02.27
} 
model. We assume that the moisture of grains changes homogeneously at all layers, thus it is sufficient to consider only one such layer. Only two phases are taken into account, i.e. the moisture in grain and air. The equations for both moisture contents are obtained using mass conservation laws. The effect of condensation within the bed of grains is assumed to be negligible.

Such a simple mathematical model is well suited for fitting the model parameters to the experimental data. At the same time we note, that the proposed model takes into account basic physical phenomena involved in drying. Thus it can be used to predict the behavior of grain moisture content and temperature for drying conditions different from those which were used to identify the coefficients of the model.

The outline of this paper is as follows. In Section 2, we state the mathematical model to be considered and formulate the finite difference scheme, which approximates the given differential problem. Then, in Section 3, we derive the stability bound and prove the error bound. The analysis is done for a linearized problem consisting of two equations. In Section 4, we present some numerical experiments to illustrate the preformance of our finite difference scheme. Finally, in Section 5 some conclusions are presented.

\section{MATHEMATICAL MODEL}

In this section we state a mathematical model and construct the finite difference scheme, which approximates the differential problem.

\subsection{Model}

Given a final time $T_{\boldsymbol{F}}>0$, we shall consider the following unsteady problem. The mathematical model is derived from the conservation laws for the moisture content in air and grain and the energy:

$$
\begin{gathered}
\varepsilon \frac{\partial c}{\partial t}+u \frac{\partial c}{\partial x}=\frac{\partial}{\partial x}\left(D(T) \frac{\partial c}{\partial x}\right)-\alpha\left(c-\frac{\beta}{\Gamma\left(T_{g}\right)}\right), 0<x<L, \\
\frac{\partial \beta(x, r, t)}{\partial t}=\frac{D_{\beta}\left(T_{g}\right)}{r^{2}} \frac{\partial}{\partial r}\left(r^{2} \frac{\partial \beta}{\partial r}\right), 0<r<R, 0<t \leqslant t_{F}, \\
\rho_{a} c_{p a}\left(\varepsilon \frac{\partial T}{\partial t}+u \frac{\partial T}{\partial x}\right)=\frac{\partial}{\partial x}\left(\lambda \frac{\partial T}{\partial x}\right)+h_{1}\left(T_{g}-T\right)+h_{1}\left(T_{a}-T\right), \\
\rho_{g} c_{g}(1-\varepsilon) \frac{\partial T_{g}}{\partial t}=\frac{\partial}{\partial x}\left(\lambda_{g} \frac{\partial T_{g}}{\partial x}\right)+h_{1}\left(T-T_{g}\right)+h_{3}\left(T_{a}-T_{g}\right) \\
+h_{4} \alpha\left(c-\frac{\beta}{\Gamma\left(T_{g}\right)}\right)+W\left(T_{g}\right) .
\end{gathered}
$$


The boundary and initial conditions are given for the moisture content in air:

$$
\begin{aligned}
& c(x, 0)=\varphi_{c}(x), \\
& c(0, t)=c_{a}\left(T_{0}\right), \\
& \left.D(T) \frac{\partial c}{\partial x}\right|_{x=L}=\eta\left(c_{a}\left(T_{a}\right)-c(L, t)\right),
\end{aligned}
$$

for the moisture content in grain:

$$
\begin{aligned}
& \beta(x, r, 0)=\varphi_{\beta}(x, r), \\
& \left.r^{2} \frac{\partial \beta}{\partial r}\right|_{r=0}=0, \\
& \left.D_{\beta}\left(T_{g}\right) R^{2} \frac{\partial \beta}{\partial r}\right|_{r=R}=\xi\left(c-\frac{\beta(x, R, t)}{\Gamma\left(T_{g}\right)}\right),
\end{aligned}
$$

and for the temperature equations:

$$
\begin{aligned}
& T(x, 0)=\varphi_{T}(x) \\
& T(0, t)=T_{0} \\
& \left.\lambda \frac{\partial T}{\partial x}\right|_{x=L}=\varkappa\left(T_{a}-T(L, t)\right), \\
& T_{g}(x, 0)=\varphi_{g}(x) \\
& -\left.\lambda_{g} \frac{\partial T_{g}}{\partial x}\right|_{x=0}=\varkappa\left(T_{0}-T_{g}(0, t)\right), \\
& \left.\lambda_{g} \frac{\partial T_{g}}{\partial x}\right|_{x=L}=\varkappa\left(T_{a}-T_{g}(L, t)\right),
\end{aligned}
$$

where $c$ is the moisture content in the air between grains, $\beta$ is the moisture content in grains, $T$ and $T_{g}$ are the air and grain temperatures, respectively. The remaining important coefficients are the following: $D$ and $D_{\beta}$ are difusivities, $u$ is the air velocity, $\rho_{a}$ and $\rho_{g}$ are mass densities, $c_{p a}$ and $c_{g}$ are specific heat capacities, $h_{j}$ are heat transfer coefficients, $\epsilon$ is the porosity, and $w\left(T_{g}\right)$ the biological heat..

Thus we have a system of semilinear parabolic equations with some coefficients depending on the solution.

\subsection{Finite Difference Scheme}

Let $\omega_{h}$ and $\omega_{H}$ be uniform partitions of intervals $[0, L]$ and $[0, R]$, respectively:

$$
\begin{aligned}
& \omega_{h}=\left\{x_{j}: \quad x_{j}=j h, j=1,2, \ldots, J-1, h=\frac{L}{J}\right\}, \\
& \omega_{H}=\left\{r_{k}: \quad r_{k}=(k-0.5) H, k=1,2, \ldots, K-1, r_{K}=R\right\} .
\end{aligned}
$$


For simplicity of notation we also assume that the temporal partition is also uniform

$$
\omega_{\tau}=\left\{t^{n}: t^{n}=n \tau, n=1,2, \ldots, N, t^{N}=T_{F}\right\} .
$$

The finite difference method gives approximations, i.e., $c_{j}^{n}, \beta_{j k}^{n}, T_{j}^{n}$ and $T_{g j}^{n}$, to the solution of the differential problem at the discrete grid points.

The good surveys of numerical methods for conservation laws and timedependent advection-dominated partial differential equations are given in [5; 9].

Before we proceed, let us introduce some notation of discrete operators

$$
\begin{aligned}
& c_{t}=\frac{c^{n+1}-c^{n}}{\tau}, \quad c_{x}=\frac{c_{j+1}-c_{j}}{h}, \quad c_{\bar{x}}=\frac{c_{j}-c_{j-1}}{h}, \\
& \beta_{r}=\frac{\beta_{j, k+1}-\beta_{j k}}{H}, \beta_{\bar{r}}=\frac{\beta_{j k}-\beta_{j, k-1}}{H} .
\end{aligned}
$$

By using the modified Finite Volume Method (FVM) we get the following system of discrete equations:

$$
\begin{aligned}
& \varepsilon c_{t}+u c_{\bar{x}}^{n+1}=\left(D_{j-0.5}\left(T^{n+1}\right) c_{\bar{x}}^{n+1}\right)_{x}-\alpha\left(c_{j}^{n+1}-\frac{\beta_{j M}^{n+1}}{\Gamma\left(T_{g j}^{n}\right)}\right), \\
& \beta_{t}=\frac{D_{\beta}\left(T_{g}^{n}\right)}{d r_{k}^{2}}\left(r_{k-0.5}^{2} \beta_{\bar{r}}^{n+1}\right)_{r}, \quad d=1 \frac{H^{2}}{12 r_{k}^{2}}, \\
& \rho_{a} c_{a}\left(\varepsilon T_{t}+u T_{\bar{x}}^{n+1}\right)=\left(\lambda_{j-0.5} T_{\bar{x}}^{n+1}\right)_{x}+h_{1}\left(T_{g j}^{n+1}-T_{j}^{n+1}\right) \\
&+h_{2}\left(T_{a}-T_{j}^{n+1}\right), \\
& \rho_{g} c_{g}(1-\varepsilon) T_{g t}=\left(\lambda_{g, j-0.5} T_{g \bar{x}}^{n+1}\right)_{x}+h_{1}\left(T_{j}^{n+1}-T_{g j}^{n+1}\right) \\
&+h_{3}\left(T_{a}-T_{g, j}^{n+1}\right)+h_{4} \alpha\left(c_{j}^{n+1}-\frac{\beta_{j K}^{n+1}}{\Gamma\left(T_{g j}^{n}\right)}\right)+W\left(T_{g j}^{n}\right) .
\end{aligned}
$$

The discrete boundary conditions for (2.13) are given by:

$$
\begin{aligned}
& c_{0}^{n+1}=c_{a}\left(T_{0}\right), \\
& \varepsilon c_{t, J}+u c_{\bar{x}, J}^{n+1}+\frac{2}{h} D_{J-0.5}\left(T^{n+1}\right) c_{\bar{x}, J}^{n+1}+\alpha\left(c_{J}^{n+1}-\frac{\beta_{J K}^{n+1}}{\Gamma\left(T_{g J}^{n}\right)}\right) \\
& =\frac{2}{h} \eta\left(c_{a}\left(T_{a}\right)-c_{J}^{n+1}\right),
\end{aligned}
$$


the discrete boundary conditions for (2.14) are the following:

$$
\begin{aligned}
& r_{0.5}^{2} \beta_{r, j 0}^{n+1}=0 \\
& \frac{R^{2} H}{2} \beta_{t, j K}+r_{K-0.5}^{2} D_{\beta} \beta_{\bar{r}, j K}^{n+1}=\xi\left(c_{j}^{n+1}-\frac{\beta_{j K}^{n+1}}{\Gamma\left(T_{g j}^{n}\right)}\right)
\end{aligned}
$$

the discrete boundary conditions for (2.15) are the following:

$$
\begin{aligned}
& T_{0}^{n+1}=T_{0}, \\
& \lambda_{J-0.5} T_{\bar{x}, J}^{n+1}=\varkappa\left(T_{a}-T_{J}^{n+1}\right),
\end{aligned}
$$

and the discrete boundary conditions for (2.16) are given by:

$$
\begin{gathered}
-\lambda_{g, 0.5} T_{g x, 0}^{n+1}=\varkappa\left(T_{0}-T_{g 0}^{n+1}\right), \\
\lambda_{g, J-0.5} T_{g \bar{x}, J}^{n+1}=\varkappa\left(T_{a}-T_{g J}^{n+1}\right) .
\end{gathered}
$$

At each time step the system splits into two parts. First we solve the linear system for new values of moisture contents $c^{n+1}, \beta^{n+1}$ and then solve the system for temperatures $T^{n+1}, T_{g}^{n+1}$.

For the practical implementation of this scheme, we solve the first system efficiently using the Picard type iterative method, which can be written in the following compact form:

$$
\left\{\begin{array}{l}
\varepsilon \frac{c^{s}-c^{n}}{\tau}=A_{1} c^{s}-\alpha\left(c^{s}-\frac{\beta_{K}^{s-1}}{\Gamma\left(T_{g}^{n}\right)}\right) \\
\frac{\beta^{s}-\beta^{n}}{\tau}=A_{2} \beta^{s}+\delta_{k K} \xi\left(c^{s}-\frac{\beta_{K}^{s}}{\Gamma\left(T_{g}^{n}\right)}\right)
\end{array}\right.
$$

where $\delta_{i j}$ is the Kronecker delta:

$$
\delta_{i j}= \begin{cases}1 & \text { if } i=j \\ 0 & \text { otherwise }\end{cases}
$$

Then the realization of each iteration splits into solving $J$ systems of linear equations with tridiagonal matrixes. The convergence of such iterative process will be proved in the next section.

The system of temperature equations can be solved using a block version of the factorization algorithm with matrix blocks of the dimension $2 \times 2$. 


\section{CONVERGENCE ANALYSIS}

In this section we consider only the part of the given finite-difference scheme, i.e. we restrict to the approximation of the moisture content equations. This simplifies the investigation of nonlinear scheme but still includes the main theoretical problems of the stability analysis: the stability with respect to boundary conditions and estimation of singularities near $r=0$.

In order also to prove that the Picard iteration method converges for sufficiently small time steps $\tau \leq \tau_{0}$ the following linear semi-implicit discrete problem is investigated:

$$
\begin{aligned}
& \varepsilon c_{t}+u c_{\bar{x}}^{n+1}=\left(D_{j-0.5}(x) c_{\bar{x}}^{n+1}\right)_{x}-\alpha\left(c_{j}^{n+1}-b_{j} \beta_{j M}^{n}\right), x \in \omega_{h}, \\
& c_{0}^{n+1}=\mu_{0} \\
& \varepsilon c_{t, J}+u c_{\bar{x}, J}^{n+1}+\frac{2}{h} D_{J-0.5} c_{\bar{x}, J}^{n+1}+\alpha\left(c_{J}^{n+1}-b_{J} \beta_{J K}^{n}\right)=\frac{2}{h} \eta\left(\mu_{1}-c_{J}^{n+1}\right), \\
& \beta_{t}=\frac{D_{\beta}\left(x_{j}\right)}{d r_{k}^{2}}\left(r_{k-0.5}^{2} \beta_{\bar{r}}^{n+1}\right)_{r}, \quad(x, r) \in \omega_{h} \times \omega_{H} \\
& r_{0.5}^{2} \beta_{r, j 0}^{n+1}=0, \\
& \beta_{t, j K}+\frac{2}{H} D_{\beta} \beta_{\bar{r}, j K}^{n+1}=\frac{2}{H} \xi\left(c_{j}^{n+1}-b_{j} \beta_{j K}^{n+1}\right) .
\end{aligned}
$$

The difference scheme can be written more compactly:

$$
\left\{\begin{array}{l}
\varepsilon c_{t}=A_{1} c^{n+1}-\gamma_{c}\left(c^{n+1}-b \beta^{n}\right), \\
\beta_{t}=A_{2} \beta^{n+1}+\gamma_{\beta} \delta_{k K}\left(c^{n+1}-b \beta^{n+1}\right),
\end{array}\right.
$$

where operators $A_{j}$ include boundary conditions.

Mathematical models of such type also arise in many other fields, such as mathematical modeling of biotechnological problems [4]. Analysis of nonlinear finite difference schemes is presented in [2].

\subsection{Approximation Error}

Let assume that solutions of the differential problem are sufficiently smooth functions in the whole region $[0, L] \times[0, R] \times\left[0, t_{F}\right]$ of the problem definition. The truncation errors of the finite difference scheme are defined as follows:

$$
\psi_{c}\left(x_{j}, t^{n}\right)= \begin{cases}c(0, t)-\mu_{0}, & j=0, \\
\varepsilon c\left(x_{j}, t^{n-1}\right)_{t}-A_{1} c\left(x_{j}, t^{n}\right) & \\
\quad+\gamma_{c}\left(c\left(x_{j}, t^{n}\right)-b_{j} \beta\left(x_{j}, r_{K}, t^{n}\right)\right), & j=1,2, \ldots, J-1, \\
\frac{2}{h}\left(\begin{array}{c}
\varepsilon c\left(x_{j}, t^{n-1}\right)_{t}-A_{1} c\left(x_{j}, t^{n}\right) \\
\left.\quad+\gamma_{c}\left(c\left(x_{j}, t^{n}\right)-b_{j} \beta\left(x_{j}, r_{K}, t^{n}\right)\right)\right),
\end{array}\right. & j=J,\end{cases}
$$


$\psi_{\beta}\left(x_{j}, r_{k}, t^{n}\right)=\left\{\begin{array}{lc}r_{0.5}^{2} \beta\left(x_{j}, 0, t^{n}\right)_{r}, & k=0, \\ \beta\left(x_{j}, r_{k}, t^{n-1}\right)_{t}-A_{2} \beta\left(x_{j}, r_{k}, t^{n}\right), & k=1,2, \ldots, K-1, \\ \frac{2}{H}\left(\beta\left(x_{j}, r_{k}, t^{n-1}\right)_{t}-A_{2} \beta\left(x_{j}, r_{k}, t^{n}\right)\right. & \\ \left.-\gamma_{\beta}\left(c\left(x_{j}, t^{n}\right)-b_{j} \beta\left(x_{j}, r_{K}, t^{n}\right)\right)\right), & k=K .\end{array}\right.$

Using the Taylor series it is easy to prove that the truncation error $\psi_{c j}^{n}$ can be estimated as:

$$
\psi_{c j}^{n}= \begin{cases}0, & j=0, \\ M_{c}(\tau+h), & j=1,2, \ldots, J-1, \\ M_{c}\left(\tau h+h^{2}\right), & j=J\end{cases}
$$

The first-order approximation in space is due to the approximation of the advection term by the upwind finite difference method. Our goal is to get the difference schemes which is free of oscillations. The approximation of the boundary condition has a second-order accuracy.

The truncation error $\psi_{\beta}^{n}$ can be represented in the following form (see, [2; 10]):

$$
\psi_{\beta k}^{n}= \begin{cases}0, & k=0, \\ \frac{D_{\beta}}{r_{k}^{2}}\left(r_{k-0.5}^{2} \eta_{k-0.5}^{n}\right)_{r}+\psi_{\beta k}^{* n}, & k=1,2, \ldots, K-1, \\ M_{\beta}\left(\tau H+H^{2}\right), & k=K,\end{cases}
$$

where

$$
\eta_{k-0.5}^{n}=\mathcal{O}\left(H^{2}\right), \quad \psi_{\beta k}^{* n}=M_{\beta}\left(\tau+H^{2}+\frac{H^{2}}{r_{k}}\right)
$$

The global error of the discrete solution can be estimated using the bounding functions, which are solutions of specially constructed stationary problems (see [2] for a similar analysis). This requires to bound the following norm of the truncation error:

$$
\begin{aligned}
\sum_{k=1}^{K-1} \frac{H}{r_{k+0.5}^{2}}\left|\sum_{p=1}^{k} H r_{p}^{2} \psi_{\beta p}^{n}\right| & \leqslant \sum_{k=1}^{K-1}\left|\eta_{k+0.5}^{n}\right| H+\sum_{k=1}^{K-1} \frac{H}{r_{k+0.5}^{2}}\left\|r \psi_{\beta}^{* n}\right\|_{\infty} \sum_{p=1}^{k} H r_{p} \\
& \leqslant R\left(\left\|\eta^{n}\right\|_{\infty}+\frac{1}{2}\left\|r \psi_{\beta}^{* n}\right\|_{\infty}\right) \leqslant M\left(\tau+H^{2}\right) .
\end{aligned}
$$

\subsection{Stability}

In order to prove that for sufficiently small $\tau \leqslant \tau_{0}$ the Picard iterative method converges to the solution of the finite difference scheme it is sufficient to 
consider the problem

$$
\left\{\begin{array}{l}
\frac{\varepsilon}{\tau} c^{s+1}=A_{1} c^{s+1}-\gamma_{c}\left(c^{s+1}-b \beta^{s}\right) \\
\frac{1}{\tau} \beta^{s+1}=A_{2} \beta^{s+1}+\gamma_{\beta} \delta_{k K}\left(c^{s+1}-b \beta^{s+1}\right)
\end{array}\right.
$$

Then using the classical maximum principle we get from the first equation that

$$
\left\|c^{s+1}\right\|_{\infty} \leqslant \frac{\tau \gamma_{c} b}{\varepsilon+\tau \gamma_{c} b}\left\|\beta_{K}^{s}\right\|_{\infty},
$$

where we have defined the discrete norm as follows:

$$
\|c\|_{\infty}=\max _{0 \leqslant j \leqslant J}\left|c_{j}\right| .
$$

For the second equation we are not attempting to prove the most accurate estimate. It is sufficient to construct a bounding function, which gives the upper estimate of $\beta^{s+1}$. This bounding function is a solution of the appropriate stationary problem and can be constructed explicitly $[2 ; 10]$. Thus the following estimate is valid:

$$
\left\|\beta_{K}^{s+1}\right\|_{\infty} \leqslant C\left\|c^{s+1}\right\|_{\infty} .
$$

Combining both estimates (3.3) and (3.4) we prove that the Picard iterative method converges for sufficiently small time steps $\tau$ :

$$
\left\|c^{s+1}\right\|_{\infty} \leqslant \frac{\tau \gamma_{c} b C}{\varepsilon+\tau \gamma_{c} b}\left\|c^{s}\right\|_{\infty} .
$$

\section{NUMERICAL EXPERIMENTS}

We consider problem (3.1)-(3.2). Our goal is to investigate the dependence of grain drying time on the air velocity $u$. Let $L=50 \mathrm{~cm}$ and $R=0.17 \mathrm{~cm}$. The other relevant parameters are chosen as follows:

$$
\begin{aligned}
& \varepsilon=0.43, \quad D=0.26 \frac{\mathrm{cm}^{2}}{\mathrm{~s}}, \quad D_{\beta}=76.8 \frac{\mathrm{cm}^{2}}{\mathrm{~s}}, \\
& \rho_{a}=0.001977 \frac{\mathrm{g}}{\mathrm{cm}^{3}}, \quad \xi=0.3, \quad \xi=0.01 .
\end{aligned}
$$

The solution satisfies the following initial and boundary conditions

$$
\begin{aligned}
& \varphi_{c}(x)=0.7, \quad c_{a}\left(T_{0}\right)=0.5, \quad c_{a}\left(T_{a}\right)=0.5 \\
& \varphi_{\beta}(x, r)=100, \quad \Gamma\left(T_{g}\right)=1 .
\end{aligned}
$$


The results are displayed in Fig. 1. The total moisture content in grains as functions of the time

$$
S(t)=\frac{3(1-\varepsilon)}{R^{3}} \int_{0}^{L} \int_{0}^{R} \beta(x, r, t) r^{2} d r d x
$$

are plotted for different air velocities $u=4.11 G$.

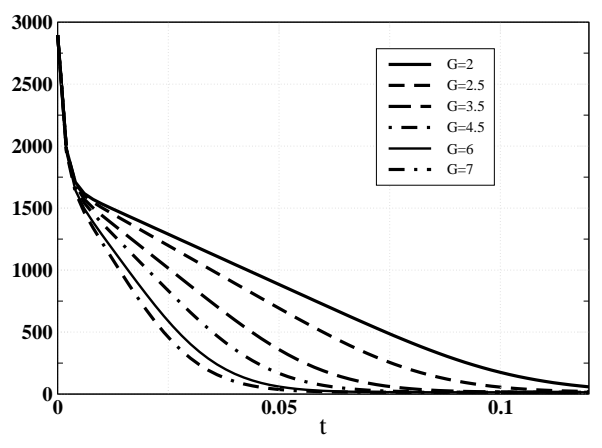

Figure 1. The total moisture content in grains

It follows from the presented results that for small $u$ the drying rate increases for increased values of $u$, but starting from $u>u_{c r}$ this rate remains practically constant.

\section{CONCLUSIONS}

In this paper a simple model was constructed to simulate the physics of grain drying. The system of differential equations is approximated by a nonlinear finite difference scheme. It is proved that a simplified discrete problem is stable and discrete solution converges to the exact solution of the differential problem. Furthermore, the applicability of the model could be extended by including more general coefficients and fitting these coefficients to the experimental data.

\section{REFERENCES}

[1] D. Brooker, F. Bakker and C. Hall. Drying and storage of grains and oilseeds. Chapman \& Hall, New York, 1992.

[2] R. Čiegis. On the convergence in $C$ norm of finite difference schemes for one nonlinear time-dependent diffusion-reaction problem. Differential Equations, 28(7), 1261 - 1271, 1992.

[3] R. Čiegis and V. Starikovičius. Mathematical modeling of wood drying process. Mathematical Modelling and Analysis, 7(2), 175 - 194, 2002. 
[4] R. Čiegis, S. Žvirblis, S. Tumas, R. Dagys and A. Pauliukonis. Mathematical modelling of kinetic process. Biotechnology, 4, 45 - 51, 1992.

[5] R.E. Ewing and Hong Wang. A summary of numerical methods for time-dependent advection-dominated partial differential equations. Journal of Comp. and Appl. Math., 128, $423-445,2001$.

[6] W.J. Ferguson and I.W. Turner. A control volume finite element numerical simulation of the drying of spruce. Journal of Computational Physics, 125, 59 - 70, 1996.

[7] D. Gu, S. Sokhansanj and K. Haghighi. Influence of floor air entry on grain moisture content, temperature, and bulk shrinkage during ambient air in-bin drying of wheat. Canadian Agricultural Engineering, 42, 185 - 194, 2000.

[8] J.M. Hermandez and J.R. Puiggali. Simulation of drying of coniferous wood using various processes. International Chemical Engineering, 34, 339 - 350, 1994.

[9] R.J. LeVeque. Numerical methods for conservation laws. Birkhäuser, Basel, 1992.

[10] A.A. Samarskij. Theory of Difference Schemes. Nauka, Moscow, 1988.

[11] S. Sokhansanj, W. Lang and D. Gu. Advances in mathematical modeling of heat and mass transfer during throughflow-air drying of cereal grain. Food Science and Technology International, 3, 226 - 234, 1997.

[12] G. C. Valenca and G. Massarani. Grain drying in counter-current and concurrent gas flow-modelling - simulation and experimental results. Drying Technology, 18, 447 $456,2000$.

[13] S. Whitaker. Heat and mass transfer in granular porous media, volume 1. HPC, New York, 1980.

\section{Grūdų džiovinimo matematinis modeliavimas}

R. Čiegis, T. Leonavičienè, V. Skakauskas, O. Suboč

Šiame straipsnyje nagrinėjama netiesinių diferencialinių lygčių sistema, aprašanti grūdų džiovinimo matematini modelį. Uždavinys sprendžiamas skaitiškai, naudojamas baigtinių tūriụ metodas. Gautoji diskrečioji schema yra konservatyvi, pasiūlytas ekonomiškas jos sprendimo algoritmas. İrodyta, kad baigtinių skirtumų schema yra stabili pradinès sąlygos, kraštinių sąlygų ir laisvojo nario atžvilgiu. Stabilumo įverčiai gauti remiantis mažoruojančių funkciju metodu, leidusiu tiksliai įvertinti singuliarinius aproksimavimo paklaidos narius taške $r=0$ ir trečiojo tipo kraštinès sąlygos aproksimavimo paklaidos poveiki globaliajai diskrečiojo sprendinio paklaidai. Pateikti skaičiavimo eksperimento rezultatai, parodantys grūdu džiovinimo laiko priklausomybę nuo oro srauto greičio džiovinimo įrenginyje. 